\title{
How Much Do Employees Matter? Comparison of Foreign and Domestic Firms' Management
}

\author{
Annamaria Kazai Ónodi \\ Corvinus University of Budapest, Hungary \\ annamaria.kazaineonodi@uni-corvinus.hu
}

\begin{abstract}
People management will be the biggest challenge for companies in the next 10 years according to EIU/SHRM survey. There are different scenarios for future work, which are influenced by economic, technological, environmental, institutional and demographic factors. This paper analysed the effect of internationalisation on human resource management based on the Hungarian Competitiveness Research Surveys 2013, 2009, 2004 and 1999. Generally, the research did not confirm that internationalisation generates higher attention towards employees, although we can find some positive tendencies. Foreign owned companies paid more attention to performance evaluation and trainings. The research identified some factors, which can be improved. For example educational cooperation with colleges and universities.
\end{abstract}

Key Words: human resource management, internationalization, export, competitiveness research

JEL Classification: F 23, M50

https://doi.org/10.26493/1854-6935.15.43-6o

\section{Introduction}

Globalisation is one of the most dominant trends nowadays, which affects our life in several ways. The advantages and disadvantages of this change had been analysed from several aspects, but this paper will focus only on employees. According to the survey of the SHRM Foundation (2014), which involved 636 executives, the top challenges that organizations will face in 5 to 10 years, will be people management. PWC (2014) described three different scenarios for future work. (1) The 'blue world,' where the corporate is the king, the driving goal is improving profits, growth and market leadership. It means 'job security and long-term service with an organisation in returns for employee commitment and flexibility' (P WC 2014, 10). (2) The 'green world,' where consumers and employees force change. The driving goal is being socially and environmentally beneficial. Social responsibility dominates the corporate agenda. Employees get life balance in return for loyalty towards the organisation. (3) The 'orange 
world', where big is bad, small is beautiful. The driving goal: maximising flexibility and minimising fixed costs at the same time. Employee value: 'Flexibility, autonomy and varied challenges in return for working on a short-term contractual basis.' (PWC 2014, 18). Which dominant trend will affect the main characteristics of HR management in the future? It depends on several economic, technological, environmental, institutional and demographic factors. In this paper, we focused only on the internationalisation process. We compared the practices of the foreign companies to the domestic owned firms. Some previous researches pointed out the higher efficiency of foreign owned firms. Does a higher level of corporate social responsibility mean higher efficiency of companies, which are becoming international? Does internationalisation support spreading the 'Blue' or 'Green' worlds?

Our other focus is on the internationalisation behaviour of domestic firms. The owners'/managers' crucial role in the internationalization process of small and medium size companies has been pointed out by several researches. The role of the management seems evident in the company's success. But what about employees? How do managers think about them? Several successful managers stated that they were only one member of a successful team, and they could not achieve the success without committed employees. Nowadays more and more attention is paid to human resource management. Do managers consider employees as crucial resources or not? This question is discussed in this paper in connection with internationalisation. The research was based on the Hungarian Competitiveness Research Surveys 2013, 2009, 2004 and 1999.

\section{Theoretical Starting Points}

The goal of this paper is not to make a systematic literature review. We only highlights some concepts, which contribute to understand the changing role of employees in globalisation. The first step is to answer the question why companies enter foreign markets, why they bear liability of foreignness. Some models emphasize the role of 'push' mechanisms, while others stress on the 'pull' mechanism. Fundamentally, four factors influence the process of internationalization (Yip 2003): governmental and regulation factors, market factors, cost factors (including economies of scale, learning and experience curves, favourable logistics, differences in country costs and skills, and product development costs) and competitive factors. Strategic goals of entering foreign markets are resourceseeking, market-seeking, improving efficiency, and improving strategic 
tools. Dunning's (1980) eclectic or OLI paradigm explains establishment of subsidiaries by ownership-specific advantages, location-specific advantages and internalization advantages. In theory, subsidiaries should operate with higher efficiency than domestic firms due to the competitive advantages of the parent company but this depends on the types of ownership-specific advantages, characteristics of host countries and the location-specific advantages.

Our opinion is that we have to make a complex review to describe the process. It is not enough to discuss the efficiency. We have to take pay attention to sustainable development as well. Dunning and Fortainer (2007) analysed multinational enterprises' effect on sustainable development in a systematic way. Direct effects: increasing host countries' savings and investments, building up sectors or industries, recapitalising inefficient local firms, effect on output, productivity, employment, working conditions, reporting system, quality standards, and level of pollution. Dunning and Fortainer (2007) highlighted that according to the 2005 KPMG survey about ' 70 percent of the largest 250 firms worldwide actively promote workforce diversity and equal opportunities, good working conditions, and effective training schemes' (p. 38). Passive effects are known as spillovers or multiplier effects (Csengödi 2011). FD I might have both positive and negative effects on domestic firms, which are influenced by the host countries' political-economic regulations, market characteristics, as well as the nature of capital invested and the motivation behind the investments. The effects can arise via different mechanisms. Navaretti and Vanables (2004) distinguish competition, factor price, and technology spillover effects as main mechanisms transmitting the effects of FDI in the host economy.

Several empirical researches verified that multinationals and their subsidiaries are the largest and the most effective companies in industries, but Konings (2001) found that foreign firms do not perform better than domestic ones in Bulgaria and in Romania. Although multinationals' advantages had been verified by most studies, explanations of this phenomenon were different. One general explanation can be that higher efficiency of subsidiaries might derive from ownership-specific advantages of parent companies (advanced technology, expertise, and knowledge capital). According to another explanation, multinationals generally enter the most profitable, highly concentrated market so an adverse selection mechanism can also explains the different efficiency. The entrance of multinationals affects market structure of host countries and influences the 
competition. Multinationals might push the less profitable companies out of the market due to their competitive advantages. The average industry productivity might be increased due to the competitive effect, but a higher market concentration has a negative effect on competition. Additional demand for resources are generated by multinationals, which has a positive effect through supply chain. However, because of the high market concentration they are able to push down the purchase price due to their bargain power. The emergence of multinational firms puts competitive pressure on domestic firms, which eventually leads to an increase in efficiency. On the other hand, local firms are able to learn from multinationals. Békés, Kleinert, and Taubal $(2009,1409)$ argued that the impact of multinationals on domestic firms depends on three factors: the intensity of the linkage, domestic firms' absorptive capacity and their ability to face competition. Békés, Kleinert, and Taubal (2009) investigated 11767 Hungarian firms between 1993 and 2002. They found that 'the presence of multinationals in the same industry increases competition on goods and factor markets and reduces the productivity of the least productive firms. More productive firms benefit more from horizontal spillovers' (2009, 1429).

Most recent Hungarian research related to this topic is by Reszegi and Juhász (2014). They compared the financial performance of 2766 domestic and 1876 foreign owned companies between 2008 and 2011. Their research did not underpin that foreign majority-owned firms were generally more productive and more profitable than the investigated domestic owned firms were. They concluded that the dual structure could be observed within foreign owned companies as well. The 'advanced' foreign owned companies had outstanding productivity, capital efficiency, technical capability and more than double average wage level compared to the other groups. The characteristics of 'low-wage' foreign owned firms lagged behind 'Advanced' companies' and were not better than Hungarian firms were. So, two significantly different company groups can be identified within foreign owned companies according to productivity and profitability. Investigating domestic firms, exporters had higher productivity and capital efficiency and paid higher wages than firms focusing on the domestic market.

In our opinion, it is not enough to concentrate on the differences between the foreign-owned and the domestic companies. If we compare a small group of effective, companies, which are becoming international to a heterogeneous crowd we can get a misleading result. It is 
a common view that exporting companies' competitiveness is behind national export competitiveness. Several researches focused on small and medium-sized companies' export activities and their influencing factors. Miocevic and Crnjanak-Karanovic (2011) concluded that cognitive and information-based capabilities influenced export performance. Sui and Baum (2014) analysed 1959 newly established Canadian SMEs, they found that the gradually internationalised firms have the highest export market survival. They concluded that although resources were crucial for all SMES, the relative importance of slack resources and innovation resources were the most important for born-global firms. Stoian, Rialp, and Rialp (2011) used regression analysis to investigate the influencing factors on export performance of Spanish smes. They concluded that managers' language skills, knowledge about international business, the firms' export commitment, and technological intensity of the industry are the most influential in export performance. DiPietro and Anoruo (2005) investigated the relation between creativity, innovation, and export performance. They discovered a positive relationship between a country's export performance and a country's creativity. Inzelt (2011a; 2011b) found positive correlation between innovation and internationalisation. Research of Halpern and Muraközy (2012) found the positive correlation among export profitability, export-intensity and innovation.

Several researches focused on the key success factors of export activities. The role of proper strategy, resources and capabilities as well as relationships were highlighted. Within resources and capabilities, the crucial role of management was emphasised by Stoian, Rialp, and Rialp (2011) and Ábel and Czakó (2013). Ruzzier at al. (2007) the research underpinned the significant effect of entrepreneurs' human capital on internationalisation. They highlighted the importance of entrepreneurs' international orientation and environmental risk perception as the two most influential factors of internationalisation. They did not find a strong positive correlation between international business skills, management expertise, and internationalisation.

The role of management in companies' success was underpinned by Bloom, Sadun, and Reenen (2012). They concluded that quarter of the cross-country and the within-country total factor productivity gaps can be accounted for by management practices. Within management practices, they focused on goal setting, motivation and control. Almost every research confirms the role of management in export success. Many researches emphasised the importance of knowledge and innovation but 
relatively few focused on employees in a direct way. For introducing the role of employees in the export success, we applied Ábel and Czakó (2013) qualitative research, which included 10 case studies. All firms had Hungarian majority ownership, were established after 1990, their exportintensity was higher than $25 \%$, employed more than 50 employees and/or had an income over one billion HUF. The case studies were based on interviews made with managing directors. Nine out of ten managers mentioned the employees' significant role in the success of the company. Two of them (managers of Csaba Metal and Bakony Müvek) highlighted the shortage of skilled workers, which meant a significant obstacle to the companies' growth possibilities. The importance of investing in human capital was emphasised by managers of Pilse Nagy, Sanatmetal and Agrofeed. The crucial role of employees' learning process was highlighted by managers of Sanatmetal, Agrofeed and Euronet. Two of them mentioned the importance of trust between employees and managers (Agrofeed and Hajdu Autotechnika Ipari Zrt). Establishing new corporate culture proved to be crucial at Gránit and at Hajdu Autotechnika Ipari Zrt. Discussing the success factors of Csaba Metal, it was mentioned that Béla Majoros, the founding owner and the CEO of the firm, could gather excellent experts, whose knowledge can be continuously broadened (Kiss 2013). It was emphasised that improvements should not stop at technology and HR, which are significant element of the company's success. All managers concluded that adequate strategy and luck were not enough for export success. Skilled and committed were needed to implement.

\section{Research Methodology and Database}

The research is based on the Hungarian Competitiveness Research databases of 2013, 2009, 2004, and 1999 launched by the Competitiveness Research Centre. All competitiveness research surveys had the same structure, containing four questionnaires (more than 100 pages altogether): top management, marketing, production, finance. As a rule, all three surveys were aimed at incorporated companies with more than 50 employees in order to build a corporate sample. The main objective was to make a database consisting of about 300 firms in all surveys. Understanding the main characteristics of the samples is crucial for making conclusions. Firms in the sample belonged to different industries, excluding the financial sector. Manufacturing companies were dominant in all databases, although the rate of them decreased from $71 \%$ to $45 \%$. The rate of service companies gradually increased from $21 \%$ to $34.7 \%$ but they were still 
under-represented because of the fact that the micro-companies were excluded from the surveys. Companies operating in the building industry, agriculture, food industry were represented in every sample. Medium sized companies dominated all databases. Their rate gradually increased; in 1999, it was $61.4 \%$, in $201372.7 \%$. In parallel with this increase, the rate of large companies fell from $32.4 \%$ to $16.7 \%$. Regarding ownership structure, the domestic owned companies dominated in all databases, the rate of them was the highest in 2009 (72.6\%), followed by $71.3 \%$ in 2013. The highest rate of foreign companies (23\%) could be observed in 2013. The rate of state owned companies decreased to $5.7 \%$ (for the descriptions of the samples of the questionnaire surveys, see Chikán, Czakó, and Zoltayné Paprika (1999; 2004; 2009), Chikán, Czakó, and Wimmer (2014), Matyusz (2011; 2014), and Lesi (2005). Managerial self-evaluations and subjective assessments dominated in the questionnaires beside financial data. The comparison of subjective assessments might cause distortion but the distortion itself reflects priority, value preference and different viewpoints.

The literature of international human resources management is broad, but the focus point is how to handle the challenges deriving from international circumstance. The other main topic is the cooperation between the HR sections of the parent company and the subsidiary (Kelly 2001) furthermore if the complexity of $\mathrm{HR}$ managers' roles and the required competencies increased with an increasing level of internationalisation (Kohont and Brewster 2014). The present research aims to answer if the foreign-owned firms deal with the human resources in a different way, if they establish a more advanced practice.

In connection with human resource management, three hypotheses were set:

$\mathrm{H} 1 \mathrm{Generally,} \mathrm{there} \mathrm{are} \mathrm{no} \mathrm{differences} \mathrm{between} \mathrm{foreign} \mathrm{and} \mathrm{domestic}$ owned companies regarding the importance of employees.

$\mathrm{H} 2$ Foreign owned companies are characterised by higher wages than domestic ones.

This hypothesis is based on Csengődi (2009) and Earle-Telegdy (2009). They concluded that foreign-owned companies paid higher wages than domestic ones in Hungary. It is an important factor. On one hand, the high salary is one of the motivation tools. It is an effective way of appreciation of the employees' performance. However, we have to take into consideration that workforce is one of the goods on the labour market, 
and the salary is the price. If the market value is high, we can be sure that the companies consider the human resources as a critical element.

$\mathrm{H} 3$ Foreign owned companies are more aware of the importance of human resource management.

These companies bring their own corporate culture with them. They use formal performance evaluation systems more frequently and spend more money on training than domestic ones. These facts does not automatically mean higher salary. Salary is more influenced by the labour market than corporate culture.

In our research, we combined two dominant research directions of the international literature forming a common method. The most commonly used method is exporters' and non-exporters, and domestic and foreign owned companies' comparison. We used two-level comparison in this research. At first, the differences between foreign and domestic owned firms were investigated. Since the earlier researches verified the high efficiency only of foreign companies, the comparison of highly efficient multinational companies (or their subsidiaries) with very heterogeneous domestic firms might result misleading conclusions. Therefore, other comparison has been conducted. The second level is the comparison of exporting foreign firms and domestic firms. More than $70 \%$ of foreign owned companies had export activities in the sample. In case of domestic firms, the presence of export activities is a significant quality criterion. The hidden research question is whether the reason of the different companies' characteristics is the owner structure or the internationalization process.

\section{Declared Values}

The first hypothesis was that there are no differences between foreign and domestic owned companies regarding the importance of employees. Two questions were selected to test this hypothesis. The first one is: How much must the interests, rights and expectations of the stakeholders be taken into account in decision-making? The managers had to evaluate the importance of stakeholder groups (owners, managers, employees, customers, suppliers, government, unions, civil society, natural environment and media) on a five-point Likert scale. According to corporate leaders, the interests of owners are those, which have to be given the highest priority when economic decisions are made. Following the owners' interests, customers,' managers,' suppliers,' employees,' and natural environment's 
interests were in the first six positions of the ranking hierarchy. Focusing on the employees' interests, unambiguous conclusions are difficult to be drawn. Comparing the given points, managers of domestic firms considered the employees' interests more important in decision-making than managers of foreign firms in 2013, 2009, and 1999, but in 2004, a reverse connection can be observed. Moreover, the ranking hierarchies suggested a slightly different picture, due to the different evaluation of other stakeholders' group. The best position of employees' interests was the fourth rank after owners, customers, managers in 2013 according to foreign companies' managers.

A significant improvement can be observed in case of domestic firms, employees' interests were placed in the sixth and seventh rank in 2009 and 2004, but in 2013, it gained the fifth position after suppliers.' During the recession, the interests of natural environment and government were considered more important, which could boggle the mind. Similar tendencies can be observed in case of foreign firms; in 1999, the importance of employees' interest in decision-making was evaluated 2.91, while in 2013 this rate increased to 3.61 . We got the lowest rank (7) in recession time too (see table 1).

Similar tendencies can be observed in case of exporting firms. Employees' interests were considered the most important in $2013(3.67,3.53)$ compared with the other years, which indicates a positive tendency, they were ranked after owners,' customers,' and managers' interests and in case of domestic firms, after suppliers.' Overall, the analysis of the first question revealed some differences between domestic and foreign owned companies, but it cannot be verified that one company group considers the employees' interests more important in decision-making than another group due to the controversial results.

The managers were asked to rank three important resources: capital and financial possibilities; the organisations' capabilities for adaptation and change and committed, excellent employees, according to their importance between 2009 and 2012. Only 14.5\% of managers considered the committed and excellent employees the most important resources, $61 \%$ of them ranked employees at the third place. The highest rate of the first rank (16.9\%) can be observed in case of domestic and exporting domestic firms. In general, the managers of domestic firms emphasised the importance of financial resources, foreign managers considered them crucial as well, but they gave slightly more emphasis to the organisations' capabilities for adaptation and change (table 2). 
TABLE 1 How Much the Interests, Rights and Expectations of the Stakeholders Must Be Taken into Account in Decision-Making?

\begin{tabular}{|c|c|c|c|c|}
\hline \multirow[t]{2}{*}{ Stakeholders' groups } & \multicolumn{2}{|c|}{ Survey of 2013} & \multicolumn{2}{|c|}{ Survey of 2009} \\
\hline & $\mathrm{D}(n=207)$ & $\mathrm{F}(n=67)$ & $\mathrm{D}(n=185)$ & $\mathrm{F}(n=42)$ \\
\hline Owners & (1) 4.33 & (1) 4.60 & (1) 4.55 & (1) 4.72 \\
\hline Managers & (3) 4.27 & (2) 4.23 & (2) 4.25 & (3) 4.14 \\
\hline Employees & (5) 3.75 & (4) 3.61 & $(6-7) 3.25$ & (7) 3.08 \\
\hline Customers & (2) 4.28 & (3) 4.21 & (3) 4.15 & (2) 4.28 \\
\hline Suppliers & (4) 3.81 & (5) 3.57 & (4) 3.53 & (6) 3.22 \\
\hline Government & $3 \cdot 32$ & 3.10 & $(6-7) 3.25$ & (5) 3.26 \\
\hline Unions & 2.28 & 2.61 & 2.47 & 2.50 \\
\hline Civil society & 2.98 & 2.63 & 2.82 & 2.69 \\
\hline Natural environment & 3.54 & 3.51 & (5) 3.28 & (4) 3.46 \\
\hline Media & 2.36 & 2.57 & 2.48 & 2.27 \\
\hline \multirow[t]{2}{*}{ Stakeholders' groups } & \multicolumn{2}{|c|}{ Survey of 2004} & \multicolumn{2}{|c|}{ Survey of 1999} \\
\hline & $\mathrm{D}(n=137)$ & $\mathrm{F}(n=55)$ & $\mathrm{D}(n=160)$ & $\mathrm{F}(n=46)$ \\
\hline Owners & (1) 4.68 & (1) 4.75 & (1) 4.68 & (1) 4.85 \\
\hline Managers & (3) 4.09 & (3) 4.04 & (2) 4.19 & (2) 4.11 \\
\hline Employees & (7) 3.13 & (5) 3.29 & (5) 3.22 & (6) 2.91 \\
\hline Customers & (2) 4.14 & (2) 4.20 & (3) 4.15 & (3) 4.05 \\
\hline Suppliers & (5) 3.21 & 3.16 & 3.21 & (5) 3.02 \\
\hline Government & (6) 3.14 & 3.00 & 3.07 & 2.84 \\
\hline Unions & 2.40 & 2.64 & 2.59 & 2.47 \\
\hline Civil society & 2.46 & 2.30 & 2.46 & 2.42 \\
\hline Natural environment & (4) 3.59 & (4) 3.47 & (4) 3.40 & (4) 3.21 \\
\hline Media & 2.31 & 2.62 & 2.31 & 2.51 \\
\hline
\end{tabular}

Notes D - domestic, F - foreign. Answers on 5-point Likert scale (5 - significant, 1 not at all significant).

Overall, the first hypothesis cannot be verified of denied due to the controversial results. Independent $t$-test underpinned statistically significant differences between domestic and foreign owned companies, but when we changed our methodology, we get controversial results. Nonetheless, some findings are relevant. Differences can be found between the way of thinking of foreign and domestic owned firms' managers but it cannot be stated firmly that one company group turns more attention towards their employees than others do. Although the importance of employees' 
TA B LE 2 What Was the Most Important Resource of Your Company between 2009 and 2012 ?

\begin{tabular}{|c|c|c|c|c|c|c|}
\hline & \multicolumn{2}{|c|}{ Rank 1} & \multicolumn{2}{|c|}{ Rank 2} & \multicolumn{2}{|c|}{ Rank 3} \\
\hline & $\mathrm{D}(n=167)$ & $\mathrm{F}(n=55)$ & $\mathrm{D}(n=167)$ & $\mathrm{F}(n=55)$ & $\mathrm{D}(n=167)$ & $\mathrm{F}(n=55)$ \\
\hline (1) & 46.8 & 43.2 & 31.0 & 27.3 & 29.5 & 29.5 \\
\hline (2) & 28.1 & 38.2 & 65.9 & 41.8 & 6.0 & 20.0 \\
\hline (3) & 16.9 & 9.1 & 16.1 & 47.7 & 66.1 & 43.2 \\
\hline
\end{tabular}

Notes Row headings are as follows: (1) capital and financial possibilities, (2) the organisations' capabilities for adaptation and change, (3) committed, excellent employees. $\mathrm{D}$ - domestic, $\mathrm{F}$ - foreign. In percent.

interest increased between 1999 and 2013, managers considered capital and financial resources more important than committed and excellent employees did in the period 2009-2012.

\section{Compensation of Employees}

The question is addressed whether the higher profitability and effective operation of foreign firms provide benefits for employees or the source of higher profitability is the exploitation of human resources. Results of former researches verified that foreign-owned companies pay higher wages than domestic ones in Hungary (Csengödi 2009; Earle and Telegdy 2009). Reszegi and Juhász (2014) emphasised the double duality in Hungarian economy, in their analysis they divided the foreign owned firms into two groups based on level of average wage. About two thirds of foreign owned companies belonged to the company group, which could be characterised by the above average wages, and a trained workforce.

Managerial self-evaluation as well as calculated figures were used to verify the second hypothesis. According to managerial self-evaluation, a higher proportion of foreign owned firms stated that they paid above industry average wages than domestic ones. In 2004 and 2013, the differences were significant. Parallel with this, the rate of firms who paid wages below the industry average was higher in case of domestic firms (see table 3). Higher wages of exporting firms cannot be verified according to managerial self-evaluation.

Calculated figures were used only to underpin the managerial selfevaluation. Figures indicated higher wages by foreign firms in the full sample, which are consistent with the managerial self-evaluation. The managerial self-evaluation did not underpin the exporting firms' higher wages. As a conclusion, we can state that hypothesis 2 was verified by 
TA B LE 3 Average Wages Compared to the Industry Average: Full Corporate Sample

\begin{tabular}{|c|c|c|c|c|c|c|}
\hline & \multicolumn{2}{|c|}{ Survey of 2013} & \multicolumn{2}{|c|}{ Survey of 2009} & \multicolumn{2}{|c|}{ Survey of 2004} \\
\hline & $\mathrm{D}(n=173)$ & $\mathrm{F}(n=57)$ & $\mathrm{D}(n=153)$ & $\mathrm{F}(n=39)$ & $\mathrm{D}(n=135)$ & $\mathrm{F}(n=56)$ \\
\hline$>125$ & 5.2 & $5 \cdot 3$ & 2.6 & 2.6 & 2.2 & 5.4 \\
\hline $110-125$ & 7.5 & 19.3 & 8.5 & 15.4 & 8.9 & 26.8 \\
\hline $90-110$ & 56.1 & 54.4 & 63.4 & 56.4 & 43.0 & 44.6 \\
\hline $75-90$ & 23.1 & 15.8 & 17.0 & 23.1 & 29.6 & 17.9 \\
\hline$<75$ & 8.1 & 5.3 & 8.5 & 2.6 & 17.0 & 7.1 \\
\hline
\end{tabular}

NOTES D - domestic, $\mathrm{F}-$ foreign. In percent.

managerial self-evaluation and calculated figures as well. This is in line with previous researches' findings.

\section{HR Practices}

$46 \%$ of foreign owned companies owned an independent HR department; this rate was only $26.3 \%$ at the exporting domestic firms, and $22.7 \%$ in the group of all domestic companies. Although the existence of independent HR departments depends on the size of the company, it is worth investigating the functions of $\mathrm{HR}$ departments more deeply.

Managers were asked to evaluate the human resources management's contributions to organisations. They were asked to evaluate eight different statements on a 5-point Likert scale according to what extent they characterised their organisations. Some differences can be observed between domestic and foreign owned companies. 'Assisting in executing organizational changes' was the most important $\mathrm{HR}$ contribution in case of foreign companies (4.17), the second one was conflict management (3.91) and the third one was being the communicational channel for representing employees' interests. Similar opinions can be observed in case of foreign owned exporters (table 4). The managers of domestic companies did not evaluate the HR management's role in change and conflict management as high as foreign companies' managers did. They emphasized the client oriented, flexible, transparent and reliable operation (3.72). The 'weakest' point of the HR management was making action plans, not just reacting to events (between 3.24 and 3.3) in case of domestic firms. Foreign owned companies are supposed to be better at making action plans (3.62). The 'weakest' point of foreign owned companies was the HR supporting roles in decision-making $(3.47,3.48)$, regarding this function the independent $t$-test did not verify differences between foreign and do- 
TABLE 4 Functions of HR Management in 2013

\begin{tabular}{|c|c|c|c|c|}
\hline \multirow[t]{2}{*}{ The role of $\mathrm{HR}$} & \multicolumn{2}{|c|}{ Full sample } & \multicolumn{2}{|c|}{ Exporting firms } \\
\hline & $\mathrm{D}(n=54)$ & $\mathrm{F}(n=34)$ & $\mathrm{D}(n=30)$ & $\mathrm{F}(n=30)$ \\
\hline $\begin{array}{l}\text { It makes the decision-making pro- } \\
\text { cess more efficient }\end{array}$ & 3.43 & 3.47 & 3.53 & 3.48 \\
\hline $\begin{array}{l}\text { It is an accepted partner in making } \\
\text { strategy decision }\end{array}$ & (5) 3.56 & (5) 3.69 & (4) 3.60 & 3.73 \\
\hline $\begin{array}{l}\text { It does not just react to events but it } \\
\text { can make action plans }\end{array}$ & $3 \cdot 30$ & 3.62 & 3.24 & 3.62 \\
\hline $\begin{array}{l}\text { It assist in executing organizational } \\
\text { changes }\end{array}$ & (3) 3.63 & (1) 4.17 & (1) 3.77 & (1) 4.20 \\
\hline $\begin{array}{l}\text { It creates and operates such commu- } \\
\text { nicational channel, which helps rep- } \\
\text { resenting the employees' interests }\end{array}$ & (4) 3.59 & (3) 3.86 & (5) 3.57 & (3) 3.86 \\
\hline $\begin{array}{l}\text { In the case of conflicts it assists in } \\
\text { reaching solutions }\end{array}$ & (6) 3.50 & (2) 3.91 & (2) 3.67 & (2) 3.97 \\
\hline $\begin{array}{l}\text { It operates in a client oriented - } \\
\text { flexible and reliable ways }\end{array}$ & $(1-2) 3.72$ & (4) 3.80 & 3.57 & (4) 3.83 \\
\hline $\begin{array}{l}\text { It operates in such a system that } \\
\text { is necessary for all organizations } \\
\text { members. }\end{array}$ & $(1-2) 3.72$ & 3.69 & (3) 3.63 & 3.70 \\
\hline
\end{tabular}

NOTES D - domestic, F - foreign.

mestic firms (table 4). Aside from the general satisfaction with human resources management, the managers of foreign owned companies emphasised the assisting role in change management, in conflict management and providing a communicational channel between employees and the company. Strategic decision-making role appeared in the first three functions only in two sub-groups (all domestic companies and exporting domestic firms).

The HR manager's role in managing organisational changes and handling conflicts is evident. Its role in strategic decision-making depends on corporate culture and corporate governance. So far, we dealt with the declared value of the importance of employees' interests and the compensation system more deeply. Only two other functions have been selected to be investigated more deeply, these are the formal performance evaluation system and trainings.

A higher rate of foreign owned companies used a formal performance evaluation system than domestic ones; the differences were underpinned 
TABLE 5 Proportion of Companies Having a Formal Performance Evaluation System in 2013

\begin{tabular}{lrrrrrr}
\hline \multirow{2}{*}{$\begin{array}{l}\text { Existence of a formal performance } \\
\text { evaluation system for }\end{array}$} & \multicolumn{2}{c}{ Full sample } & & \multicolumn{2}{c}{ Exporting firms } \\
\cline { 2 - 3 } & $\mathrm{D}(n=198)$ & $\mathrm{F}(n=65)$ & & $\mathrm{D}(n=55)$ & $\mathrm{F}(n=89)$ \\
\hline Wide range of employees & 33.3 & 43.1 & & 36.0 & 43.6 \\
Key employees & 32.2 & 49.2 & & 36.7 & 56.4 \\
Managers & 32.0 & 47.7 & & 37.1 & 54.5 \\
\hline
\end{tabular}

NOTES D - domestic, F - foreign. In percent.

TABLE 6 Proportion of Companies Using the Output of a Formal Performance Evaluation System for Specific Purposes in 2013

\begin{tabular}{lrrrrr}
\hline \multirow{2}{*}{$\begin{array}{l}\text { Purposes for which the output of the } \\
\text { perf. evaluation system was used }\end{array}$} & \multicolumn{2}{c}{ Full sample } & & \multicolumn{2}{c}{ Exporting firms } \\
\cline { 2 - 3 } Compensation & 74.5 & 73.7 & & 74.3 & 75.5 \\
Promotions & 52.8 & 67.9 & 43.3 & 64.6 \\
Other administrative decision & 29.0 & 22.6 & 37.5 & 26.7 \\
Trainings & 30.7 & 41.8 & 35.9 & 44.7 \\
Inner communication & 40.9 & 37.7 & 33.3 & 37.8 \\
Not used & 17.0 & 17.6 & 13.3 & 21.4 \\
\hline
\end{tabular}

NOTES D - domestic, F - foreign. In percent.

by an independent $t$-test. More than half of companies in all subgroup have no formal performance evaluation system for a wide range of employees. The highest rate $(56 \%)$ could be observed in case of foreign owned exporters. Foreign owned companies focused on measuring key employees' performance (49.2\%), after that the managers' performance (47.7\%), and only $43.1 \%$ of them have a formal performance evaluation system for a wide range of employees (table 5 ).

In every group the usage of such output for compensation purposes was the most frequent, and following that were promotion, training and inner communicational purposes, but the application rates were different based on statistic tests (see table 6).

The other selected area is training program. More than half of the interviewed domestic companies had any training plan and this proportion was over $70 \%$ in case of foreign owned firms. It is consistent with KSH (2007) survey, which pointed out that $49 \%$ of Hungarian companies with more than 10 employees supported trainings, and almost every large company did it. The proportions of external and internal trainings 
TABLE 7 Proportion of Different Types of Trainings Based on the Competitiveness Research Survey of 2013

\begin{tabular}{lcrrrrr}
\hline Different types of trainings & \multicolumn{2}{c}{ Full sample } & & \multicolumn{2}{c}{ Exporting firms } \\
\cline { 2 - 3 } & $\mathrm{D}(n=197)$ & $\mathrm{F}(n=63)$ & & $\mathrm{D}(n=57)$ & $\mathrm{F}(n=90)$ \\
\hline Continuous external trainings & 32.5 & 30.2 & & 46.7 & 35.2 \\
$\begin{array}{l}\text { Continuous internal trainings (own } \\
\text { teachers and programs) }\end{array}$ & 39.1 & 76.2 & & 47.8 & 75.9 \\
$\begin{array}{l}\text { Educational cooperation with col- } \\
\text { leges or universities }\end{array}$ & 12.3 & 4.8 & & 16.7 & 5.6 \\
Ethics trainings & & & & & \\
\hline
\end{tabular}

NOTES D - domestic, F- foreign. In percent.

were different in case of foreign and domestic firms. In all domestic subgroups the application rate of external and internal trainings were very similar. Foreign owned companies preferred internal trainings, applied twice as external trainings. Less than third of the companies had ethics trainings in all sub-groups, the highest rate $(27.8 \%)$ can be observed at foreign owned exporters. The weak point of foreign firms is the educational cooperation with colleges or universities, less than $10 \%$ had any cooperation. In this area, the domestic firms proved to be the better (table 7).

\section{Conclusion}

The paper was addressed to investigate the effect of internationalisation on human resource management based on the Hungarian Competitiveness Research Surveys 2013, 2009, 2004, and 1999. The research was limited to Hungarian located companies.

Considering employees' interests, the longitudinal analysis showed an improving tendency. The research revealed some differences between domestic and foreign owned companies, but it cannot be verified that one company group considers the employees' interests more important in decision-making than another group. Although several managers and authors emphasised the crucial role of human resources in company success, our survey did not confirm this general opinion. Only 14.5\% of managers considered the committed and excellent employees as the most important resources. The majority of them emphasised the importance of financial resources, which is consistent with the fact that owners' interest proved to be the most important in decision making according to managers.

The second hypothesis, that foreign owned companies are charac- 
terised by higher wages than domestic ones was verified, which is consistent with previous researches.

In case of foreign companies, managing organisational changes and handling conflicts were the most common characteristics of HR management. The managers of domestic companies did not evaluate the $\mathrm{HR}$ management's role in change and conflict management as high as foreign companies' managers did. They emphasized the client oriented, flexible, transparent and reliable operation. HR role in decision-making should be improved in both groups. A higher rate of foreign owned companies used a formal performance evaluation system than other subgroups. A higher rate of foreign owned companies provided trainings. Foreign owned companies preferred internal training. The weak point of foreign firms is the educational cooperation with colleges or universities, less than $10 \%$ had any cooperation.

Although more and more attention has been turned toward human resource management in theory, the findings show controversial pictures. Numerous successful managers claimed that financial resources are more important than human resources are. In this area, we expect a change in the future, although it depends on the institutional and market environment. The research highlighted different characteristics of firms. The implementation of a formal performance evaluation system is recommended for beyond a certain company size, for everyone. Foreign owned companies should measure not just the key employees' performance, but a wider range of employees.' This might lead to an increase in efficiency. The role of HR management in decision-making should be increased. Presumably, domestic firms can learn from foreign owned companies about how to organize internal trainings, but foreign companies should build up more connections with universities and colleges.

\section{References}

Abel, I., and E. Czakó. 2013. Exportsiker nyomában. Budapest: Alinea.

Békés, G., J. Kleinert, and F. Taubal. 2009. 'Spillovers from Multinationals to Heterogeneous Domestic Firms: Evidence from Hungary.' World Economy 32 (10): 1408-33.

Bloom, N., R. Sadun, and J. Reenen. 2012. 'Does Management Really Work?' Harvard Business Review 90 (11): 76-82.

Chikán, A., E. Czakó, and Z. Zoltayné Paprika. 1999. Arccal a piac felé: gyorsjelentés az 1999. évi kérdőíves felmérés eredményeiröl. Budapest: Budapesti Corvinus egyetem. 
— 2004. Fókuszban a verseny: gyorsjelentés a 2004. évi kérdöíves felmérés eredményeiről. Budapest: Budapesti Corvinus egyetem.

- 2009. A vállalati versenyképesség válsághelyzetben: gyorsjelentés a 2009. évi kérdőíves felmérés eredményeiről. Budapest: Budapesti Corvinus egyetem.

Chikán, A., E. Czakó, and Á. Wimmer 2014. Kilábalás göröngyös talajon: gyorsjelentés a 2013. évi kérdöíves felmérés eredményeiről. Budapest: Budapesti Corvinus egyetem.

Csengődi, S. 2009. 'Foreign Capital and Wages in Hungary'. PhD dissertation, Corvinus University of Budapest.

DiPietro, W. R., and E. Anoruo. 2005. 'Creativity, Innovation, and Export Performance.' Journal of Policy Modeling 28: 133-8.

Dunning, J. H. 1980. 'Toward an Eclectic Theory of International Production: Some Empirical Tests.' Journal of International Business Studies 11 (1): 9-31.

Dunning, J. H., and F. Fortainer. 2007. 'Multinational Enterprises and the New Development Paradigm: Consequences or Host Country Development.' Multinational Business Review 15 (1): 25-46.

Earle, J., and Á. Telegdy. 2008. 'Ownership and Wages: New Evidence from Linked Employer-Employee Data in Hungary, 1986-2003.' In Analysis of Firms and Employees: Qualitative and Quantitative Approaches, edited by F. Andersson, S. Bender, K. Shaw, and T. Von Wachter, 22952. Cambride, mA: Chicago: University of Chicago Press.

Halpern, L., and Muraközy, B. 2009. 'Innovation, Productivity and Exports: The Case of Hungary' Economics of Innovation and New Technology 21 (2): 151-73.

Inzelt, A. 2011a. 'Innováció határok nélkül: bevezető a tematikus számhoz.' Külgazdaság 55 (September-October): 3-21.

— 2011b. 'Innováció és nemzetközi terjeszkedés a kicsik világában: egy e-felvétel eredményei.' Külgazdaság 55 (September-October): 122-54.

Kiss, J. 2013. 'Csaba Metál: exportsikerek a kukoricaföldek szomszédságában.' In Az exportsiker nyomában, edited by I. Ábel and E. Czakó, 169-76: Budapest: Alinea.

Kelly, J. 2001. 'The Role of the Personnel/HR Function in Multinational Companies.' Employees Relations 23 (6): 536-57.

Kohont, A., and C. Brewster. 2014. 'The Roles and Competencies of HR Managers in Slovenian Multinational Companies.' Baltic Journal of Management 9 (3): 294-313.

Konings, J. 2001. 'The Effects of Foreign Direct Investment on Domestic Firms: Evidence from Firm-Level Panel Data in Emerging Economies. Economics of Transition 9 (3): 619-33. 
Lesi, M. 2005. A 2004-es versenyképesség kutatás vállalati mintájának alapjellemzői és reprezentativitása. Budapest: Budapesti Corvinus egyetem.

Matyusz, Z. 2011. A 2009-es versenyképességi adatfelvétel vállalati mintájának alapjellemzői és reprezentativitása. Budapest: Budapesti Corvinus egyetem.

Matyusz, Z. 2014. A 2013-as versenyképességi kutatás vállalati mintájának alapjellemzői és reprezentativitása. Budapest: Budapesti Corvinus egyetem.

Miocevic, D., and B. Crnjanak-Karanovic 2011. 'Cognitive and InformationBased Capabilities in the Internationalization of Small and MediumSized Enterprisess: The Case of Croation Exporters.' Journal of Small Business Management 49 (4): 537-57.

Navaretti, B. G., and A. J. Vanables. 2004. Multinational Firms in the World Economy. Princeton, NJ: Princeton Universty Press.

PWC. 2014. 'The Future of Work: A Journal to 2022.' https://www.pwc.com/ $\mathrm{gx} / \mathrm{en} / \mathrm{managing}$-tomorrows-people/future-of-work/assets/pdf/future -of-rork-report-v16-web.pdf

Reszegi, L., and P. Juhász. 2014. A vállalati teljesítmény nyomában. Budapest: Alinea.

Ruzzier, M., B. Antoncic, R. Hisrich, and M. Konecnik. 2007. 'Human Capital and SME Internationalization: A Structural Equation Modelling Study.' Canadian Journal of Administrative Sciences 21 (1): 18-29.

SHRM. 2014. 'Challenges for Human Resource Management and Global Business Strategy' http://futurehrtrends.eiu.com/report-2014/ challenges-human-resource-management/

Stoian, M. C., A. Rialp, and J. Rialp. 2011. 'Export Performance under the Microscope: A Glancethrough Spanish Lenses.' International Busisess Review 20:117-35.

Sui, S., and M. Baum 2014. 'Internalization Strategy, Firm Resources and the Survival of smes in the Export Market.' Journal of International Business Studies 45 (7): 821-41.

Yip, G. 2003. Total Global Strategy. London: Financial Times.

This paper is published under the terms of the Attribution-

NonCommercial-NoDerivatives 4.o International (CC B Y-NC-ND 4.0)

License (http://creativecommons.org/licenses/by-nc-nd/4.o/). 